International Journal of Engineering \& Technology, $7(3.2)(2018)$ 54-58
International Journal of Engineering \& Technology
SPC
Website: www.sciencepubco.com/index.php/IJET
Research paper

\title{
Comparative Legal Analysis of the Legislation of Labor Protection in Construction Using the Example of the EU, Azerbaijan and Ukraine
}

\author{
Volodymyr Bozhko ${ }^{1^{*}}$, Inna Kulchii ${ }^{2}$, Joanna Szydło ${ }^{3}$ \\ ${ }^{1}$ Poltava Law Institute Of Yaroslav Mudryi National Law University, Ukraine \\ ${ }^{2}$ Poltava National Technical Yuri Kondratyuk University, Ukraine \\ ${ }^{3}$ Bialystok University Of Technology, Poland \\ *Corresponding Author: E-Mail:Volodya_Bozhko@Ukr.Net
}

\begin{abstract}
The present article deals with the legislation on labor protection in the construction of the European Union and compares it with the law of Ukraine and Azerbaijan. The main focus of the paper is on Council Directive 92/57/EEC of 24 June 1992 on the implementation of minimum safety and health requirements at temporary or mobile construction sites. Comparing its content with the legislation on labor protection at the construction sites of Ukraine and Azerbaijan, the authors conclude that the guarantees of the right to labor protection in the EU cover a much wider range of subjects than in other states. This is due to the fact that the term «worker», in accordance with the case-law of the Court of Justice, covers persons who performs services for and under the direction of another person; pursues real, genuine activities, to the exclusion of activities on such a small scale as to be regarded as purely marginal and ancillary; in return for which he receives remuneration. In addition, guarantees of labor protection in the EU extend to the self-employed person, whose professional activity contributes to the completion of a project. Proposed ways to adapt Ukrainian and Azerbaijani legislation to EU law.
\end{abstract}

Keywords: Decent work, EU law, Labor safety, Legislation on labor protection in construction, Worker.

\section{Introduction}

The relevance of the topic is due to the fact that the International Labor Organization (hereinafter - ILO), with the aim of preventing occupational accidents and occupational disease, celebrates the World Health and Safety Day every year on April 28. This year's event is intended to draw the attention of the international community to new trends in occupational health and safety, and to the scale of injuries, illnesses and deaths worldwide as a result of industrial accidents [1].

According to the ILO, more than 2.78 million deaths occur each year as a result of accidents at work or occupational diseases. In addition, every year, about 374 million workers receive occupational injuries or illnesses, most of which lead to a permanent loss of their ability to work. Annual economic losses from such a state of safety of production are estimated by the ILO at $3.94 \%$ of world gross domestic product [2].

In contrast, according to Pawei Hammalyainen, Yuki Takala and Tan Bun Kyat, more than 7500 people died every day, 1000 of which were from work-related accidents and 6500 were from work-related illnesses. The amount of such cases has slightly increased in recent years [3].

That is why at the jubilee 70th session of the UN General Assembly in New York, on September 25-27, 2015, the United Nations Summit on Sustainable Development took place, which resulted in the adoption of the program «Transforming our world: a sustainable development agenda to 2030», in which 17 Sustainable Devel- opment Goals were formulated as well as 169 objectives for the implementation of these goals [4].

The eighth objective is as follows: «Promoting sustainable, comprehensive and sustainable economic growth, full and productive employment and decent work for all», one of the objectives of which is the protection of labor rights, as well as the promotion of a safe working environment for all workers (task 8.8. ).

Azerbaijan, Ukraine, together with other UN member states, have joined the global process of ensuring sustainable development. To ensure sustainable development of Ukraine by 2030, the Ministry of Economic Development and Trade of Ukraine developed and presented the National Report «The Objectives of Sustainable Development: Ukraine», which sets out the benchmarks for achieving Ukraine's Sustainable Development Goals [5].

The national report states that sustainable economic growth is impossible without full and productive employment and decent work for all women and men, as well as the protection of labor rights for safe working conditions for all workers (p. 10). That is why one of the tasks should be the desire «to promote safe and secure working conditions for all workers, in particular through the applying of the innovative technologies in the field of occupational safety and industrial safety» (task 8.5, p. 63). Indicators that will measure progress on this task will be: the number of victims of work-related accidents that resulted in disability for 1 business day or more, as a percentage of 2015 (indicator 8.5.1); the number of deaths from industrial accidents, as a percentage of 2015 (indicator 8.5.2); the part of workers employed in work with harmful working conditions, in the total number of full-time employees, as a percentage (indicator 8.5.3.) (p. 63). 
Such increased attention to working conditions is due to the fact that according to official statistics of the State Service of Ukraine for Labor, in the 12 months of 2017 in Ukraine there have been 4313 accidents with fatal consequences and group accidents related to the production, of which in the construction industry - 224 accidents, while in 2016 - 4428 and 184 incidents respectively. That is, while the total number of accidents in Ukraine in the past year decreased by $2.6 \%$, in construction sphere their number increased by $21.7 \%$ [6].

In the implementation of the «Agenda for Sustainable Development until 2030», a documentary national review «Azerbaijan 2030. From the Millennium Development Goals to Sustainable Development» was developed in the Azerbaijani Republic [7].

An easy way to comply with the paper formatting requirements is to use this document as a template and simply type your text into it.

In order to achieve the «Agenda», in accordance with the Decree of the President of the Republic of Azerbaijan dated March 16 , 2016, No. 1897 «On approval of the main directions of the strategic road map for the national economy and the main sectors of the economy and the problems arising from it» and its Decree dated December 6, 2016 In the year «On Approval of Strategic Plans for the National Economy and Main Economic Sectors», strategic road maps for the development of the national economy in general and eleven sectors of the economy in particular were developed.

\section{Main Body}

The European Union, although not a member of the UN and the ILO, also seeks to prevent occupational injuries and occupational diseases in general and in construction in particular. In its annual report on the implementation of the EU Strategic Framework for Health and Safety at Work 2014-2020 in 2015, the European Parliament also drew the attention of the European Commission to the importance of complying with labor protection legislation and stressed the need to protect all workers independently the size of the employer, the type of work or contract [8].

This concern of the European Parliament is due to the fact that more than 4,000 workers died every year after an industrial accident in the EU, and about three million people were victims of industrial accidents, which resulted in them being absent from work on average for three days [9].

Despite the fact that during 2007-2013, the number of workers affected by an accident at work decreased by $9.8 \%$ [10], the level of occupational injuries in the EU still remains high. Almost $8 \%$ of workers suffer from work-related accidents [11], and according to the findings of the European Agency for Safety and Health at Work (EU OSHA), each year the European economy suffers a loss of EUR 476 billion [12].

However, according to the European Commission, an investment of EUR 1 in labor protection even brings income from 1.29 to 2.89 euros [13], and experts from the International Association for Social Security estimate the profitability of such an investment at 2.2 euros [14]. The same may be the reason why workers' rights to occupational safety are consistently enshrined in the constituent acts of the EU?

In particular, paragraph 3 of Part I of the European Social Charter states that all workers have a right to safe and healthy working conditions [15].

The content of this right is disclosed in Article 3, Part II of the Charter, as follows: In order to ensure the effective right of safety and healthy working conditions, the Parties undertake: 1 . to develop, implement and periodically review consistent national policies in the field of occupational safety, occupational hygiene and production the environment. The main objective of this policy is to improve occupational and occupational health and to prevent accidents and injuries resulting from or associated with the production activity, in particular by minimizing the causes of the risks inherent in the production environment; 2. Adopt safety and health regulations; 3. Ensure that such rules are implemented by enforc- ing compliance with their requirements; 4. promote the gradual development of occupational health services for all employees whose main task is to carry out preventive and advisory functions. Paragraphs 7, 19 of the Title I of the Charter of Fundamental Social Rights of Workers (1989) proclaim that the formation of a common internal market should lead to an improvement in the living standards and working conditions of workers in the European Community; each worker must have satisfactory and safe working conditions, and this requires appropriate measures to further harmonize working conditions.

According to Article 31 (1) of the Charter of Fundamental Rights of the European Union (2000), each worker has the right to work in conditions that ensure the protection of his health, his safety and respect for his dignity [16].

On December 17, 2017, the European Parliament, the Council and the European Commission at the special meeting on fair work and economic growth held in Gothenburg, Sweden jointly and solemnly signed the European pillar of social rights [17]. According to Article 10 of the European Pillar of Social Rights, workers have the right to a high level of protection of their health and safety at work (a); on the workplace, adapted to professional needs, enabling them to continue their participation in the labor market (b). In addition to the above, there are a number of secondary legislation in the EU aimed at regulating occupational safety and health in construction. In particular, Council Directive 89/391 / EEC of 12 June 1989 on the introduction of measures to encourage improvements in the safety and health at work of workers [18], and a special Council Directive 92/57/EEC of 24 June 1992 on the implementation of the minimum safety and health requirements hygiene on temporary or mobile construction sites (eighth individual Directive within the meaning of Article 16 (1) of Directive 89/391/EEC) [19].

The EU's attention to occupational safety in the construction industry is due to the fact that almost half of all accidents occur on construction sites, especially those where several subcontractors operate simultaneously [20].

Workers on construction sites are seriously threatened, which should include a high risk of accident (in 2012, the level of occupational injuries in the construction sector was twice as high as in other areas, and fatal accidents occurred three times more often [21]). In addition, complex subcontracting [22] and a large number of self-employed people involved in construction [23] complicate work and contribute to increased occupational injuries on the construction site.

The fact that, by concluding association agreements with other states, the EU prompts the EU to oblige them to adapt their legislation, including Directives 89/391 / EEC and 92 / 57 / EEC [24]. However, in the Association Agreement between the European Union and its member states, on the one hand, and Ukraine, on the other hand [25], which, after a long process of ratification by parliaments of all $28 \mathrm{EU}$ Member States and the Verkhovna Rada of Ukraine, came into force in full from September 1, 2017 Ukraine did not take such a responsibility on itself. But this did not prevent the Ministry of Social Policy of Ukraine from June 23, 2017, the number 1050, registered in the Ministry of Justice of Ukraine on September 08, 2017 under the number $1111 / 30979$ to approve «Minimum requirements for labor protection on temporary or mobile construction sites» [26]. As stated in paragraph 3 of the «Minimum Requirements», they have been developed on the basis of Directive 92/57 / EEC of the European Parliament and of the Council of 24 June 1992 on minimum safety and health requirements for temporary or mobile construction sites (eighth a separate Directive within the meaning of Article 16 (1) of Directive $89 / 391$ / EEC) (hereinafter referred to as «Minimum requirements»). The same Ukraine voluntarily brought its legislation in line with EU law in the field of labor protection in construction. But is the legislation of the EU and Ukraine in fact harmonized in this area? After all, the Court of Justice of the European Union (hereinafter - the EU Court) repeatedly drew attention of certain EU member states to the fact that their legislation was not brought into line with Directive 92/57 / EEC [27]. 
In accordance with paragraph 1 of the section «I. These Minimum Requirements» establish common rules for the organization of occupational safety and work at temporary or mobile construction sites in the course of construction work in accordance with the list of types of construction works covered by the minimum requirements specified in Annex 1 to these Minimum Requirements.

In accordance with this appendix, it specifies an exhaustive list of types of construction works for which the following Minimum Requirements should be applied, in particular, for: underground works, except for works related to the extraction of ore and nonmetallic minerals underground, as well as with construction and the exploitation of underground mines created during the development of mineral deposits in an open way; earthworks, including arranging artificial earthworks; construction of external engineering networks; arrangement of artificial bases and foundations stone, installation, concrete, reinforcing, insulating, roofing, finishing works, including installation of heat-insulating facade systems; electrical works; installation and testing of internal engineering equipment and networks; underwater works; new construction; reconstruction; technical re-equipment; Major repairs; restoration; dismantling; demolition; current repair during operation; exploitation and maintenance of structures, if they relate to any of the above-mentioned types of work.

In the first place, in Appendix I to Directive 92/57/EEC, an incomplete list of construction works, in which compliance with the requirements of the act is obligatory, is indicated. Secondly, attention is drawn to the fact that in the Minimum Requirements, outlining the types of construction works, a variety of phenomena are combined: types of construction works (eg underground or earthworks, etc.) and types of construction (for example, new construction, reconstruction, technical re-equipment, capital repair, restoration, etc.). The method used to formulate the list of construction works contradicts not only Annex I of Directive 92/57 / EEC but also the «List of construction works that do not require the documents giving the right to fulfill them and after which the object is not subject to acceptance», approved by the Resolution of the Cabinet of Ministers of Ukraine of June 7, 2017, No. 406. In our opinion, when formulating this list, it is necessary to use the approach outlined in Directive 92/57/EEC and not to list all possible types of construction works, and to be conclusively named and types under which these minimum requirements will not apply. In accordance with paragraph 2 of the section «I. General, these Minimum requirements» apply to customers, construction managers, general contractors, contractors, subcontractors, individuals who provide themselves with their own work. Section 5 of this section of the Minimum Requirements contains the definition of all the newly listed entities.

An analysis of the list leads to a number of questions. Firstly, it is surprising that the minimum requirements are not applied to employers and employees. Secondly, the individual who provides himself with work independently, is suggested to be considered as the individual who performs work on the construction site under a civil law contract concluded with the customer or the contractor. However, if an individual has the status of a private entrepreneur, then as an entity, it concludes with other entities not civil law, and economic contracts. In this case, he does not compile with the the status of «the individual who provides himself with work on his own» in the sense of paragraph 2 of the section «I. General provisions» Minimum requirements? Accordingly, under Article 2 (d) of Directive 92/57/EEC, a self-employed person understands any person other than the worker and the employer whose professional activities contribute to the completion of the project.

The definition of the list of categories of persons relating to workers, employers and self-employed persons is of the utmost importance, in accordance with Article 6 (b, d) of Directive 92/57/EEC, the employer, the occupational safety and health coordinator at the stage of implementation the project is obliged to provide protection against accidents not only workers, but also those who provide themselves with work.

Instead, in the section «IV. Labor Protection Coordinators «Minimum requirements stated that» the coordinator of occupational safety at the construction stage is required to coordinate the implementation of measures aimed at ensuring compliance by contractors and self-employed persons with the requirements of Section VI of these Minimum Requirements, the Work Plan for the Construction Site and the Regulations -legal acts on occupational safety» (subparagraph 2 of clause 2); «To organize the cooperation of contractors, including those who change each other, and coordinate their actions to protect workers and to prevent accidents at work and occupational diseases. To organize the mutual exchange of information between contractors, employees, their representatives and self-employed persons» (sub-paragraph 4 of item 2), etc.

In this part of the study, the minimum requirements are in accordance with the current Ukrainian and Azerbaijani legislation on labor protection, since only employees who work in the enterprise, in the institution, organization and perform duties or functions in accordance with an employment contract (contract) cover the guarantees of protection against an accident (Article 1 of the Law of Ukraine «On Occupational Safety»; Article 10, Clause 10, Clause d) of Article 6, Articles 209, 215, 218, 222 of the Labor Code of the Republic of Azerbaijan, approved by the Law of the Azerbaijan Republic from 1 February 1999 №618- IQ). However, they are contrary to Directive 92/57/EEC.

In addition, in the EU, the meaning of the term «worker», which is subject to guarantees of protection in the field of labor protection, is much broader than in Ukraine and the Republic of Azerbaijan. This is supported by the case law of the Court of Justice of the European Union. In particular, in its judgment of 21 February 2018 in case C-518/15, the Court of Justice emphasized that «the concept of worker ... can not be interpreted differently in accordance with the laws of the Member States, it has an autonomous meaning specific to the EU». And further: «According to a wellestablished case-law, any person who carries out real and genuine activities, except for measures that should be considered purely marginal and auxiliary, should be considered as an «worker». The decisive feature of labor relations is that for a certain period of time such person provides services to another person and under its guidance, for which he receives remuneration» (paragraph 28 of the said Decision).

Similar legal positions are reflected in paragraph 25 of the judgment in Case C-316/13 and paragraph 28 of the judgment in Case C-428/09.

«... in accordance with the case-law of the Court, the term «worker» ... must be determined in accordance with objective criteria that distinguish labor relations in terms of the rights and obligations of the persons concerned. Consequently, any person who carries out a genuine activity, with the exception of smallscale measures, to be considered purely marginal and auxiliary, should be regarded as an «worker». An essential feature of labor relations is that for a certain period of time such a person provides services under the direction of another person and under his guidance, for which he receives remuneration» (paragraph 27 of the Judgment in case C-316/13). Similar findings are reflected in paragraph 28 of the judgment in Case C-428/09 and paragraph 23 of the Judgment in Case C-337/10.

«According to the case-law of the Court, the most important feature of labor relations is that for a certain period of time a person provides services for and under the direction of another person, for which receives a remuneration whose legal characteristics, in accordance with national law, the form, as well as the nature of legal relations between these two persons are not decisive in this regard», the EU Court emphasizes in paragraph 27 of its judgment of 17 November 2016 in case C-216/15 [30].

«The subjective nature of labor relations under national law can not have any consequences as to whether that person is an employee for the purposes of EU law. This means that ... the fact that people with special needs ... are subject only to some of these conditions, this can not prevent the potential classification of such persons as «workers» (paragraph 30 of the Opinion of Advocate General Mengozzi in Case C-316/13 of June 12, 2014). 
In its Decision of 13 January 2004 in case C-256/01 between Debra Allongby and the Accrington \& Rossendale College, the EU Court stated that «the formal classification of a self-employed person under national law does not exclude the possibility that such a person should be classified as an employee within the meaning of Article 141 (1) EC, if its independence is only conditional, which only masks the employment relationship» [31] (paragraph 71 of the judgment in case C-256/01).

On the other hand, in paragraph 68 of the judgment in Case C256/01, the Court of Justice states: «... the authors of the Treaty did not intend that the term «worker» within the meaning of Article 141 (1) of the EC could include independent suppliers of services which have no relations subordination with the person receiving the service».

Thus, an employee differs from other EU labor law subjects, in line with the legal position of the EU Court, in that he:

- provides services for and under the direction of another person; - carries out real and genuine activities, with the exception of activities of a small scale, similar to marginal and auxiliary; - receives remuneration.

That is why Article 3 (a) of the General Council Directive 89/391/EEC of 12 June 1989 on the introduction of measures to improve the safety and health of workers at work [32] states that an employee is to be considered as any person employed by the employer in including as a student, with the exception of domestic servants.

\section{Conclusions}

All things considered, one may conclude that labor protection in construction is a topical issue not only for Ukraine and Azerbaijan but also for the EU. This is evidenced by an analysis of relevant legislation and law enforcement practices. Comparative analysis of the EU law with legislation of other countries shows existence of similar requirements of legislators to health and safety at construction sites in different countries. In other words, the content and scope of labor protection rights in the EU, Ukraine and Azerbaijan are approximately the same. However, these countries differ significantly in the range of persons covered by labor protection legislation. In the EU, it includes self-employed persons and, according to the case-law of the Court of Justice, «worker» including persons who simultaneously comply with the following requirements: they perform services for and under the direction of another person; pursue real, genuine activities, to the exclusion of activities on such a small scale as to be regarded as purely marginal and ancillary; in return for which they receive remuneration. In our view, covering these subjects of labor protection legislation will encourage employers not to avoid cocluding an employment contract with persons whose work they use at construction sites, saving on wages and contributions to the social insurance fund, and thus contribute to enforcement the right of more people to work in decent conditions.

\section{References}

[1] World Day - 28 April, http://www.ilo.org/moscow/areas-ofwork/occupational-safety-and-health/WCMS_305902/lang-en/index.htm.

[2] Safety and health at work, http://www.ilo.org/global/topics/safetyand-health-at-work/lang--en/index.htm

[3] Hämäläinen P., Takala J., Boon Kiat T., Global Estimates of Occupational Accidents and Work-related illnesses 2017, P.11, available online:

http://www.icohweb.org/site/images/news/pdf/Report\%20Global\% 20Estimates $\% 20$ of $\% 20$ Occupational $\% 20$ Accidents $\% 20$ and $\% 20 \mathrm{Wo}$ rk-related\%20Illnesses\%202017\%20rev1.pdf.

[4] Transforming our world: the 2030 Agenda for Sustainable Development,

https://sustainabledevelopment.un.org/post2015/transformingourwo rld.

[5] National Report «The Objectives of Sustainable Development: Ukraine» provides a vision for benchmarks for achieving Ukraine's goals of sustainable development, available online: http://un.org.ua/images/sdgs_nationalreportua_web_1.pdf.

[6] Statistical data on occupational injuries since the beginning of the year, http://dsp.gov.ua/statystychni-dani-vyrobnychoho-travma-2/.

[7] Azerbaijan - 2030: from the millennium development goals towards the sustainable development goals. Voluntary National Review of the Republic of Azerbaijan on the first steps in the implementation of the 2030 Agenda for Sustainable Development Drafted for submission to the High-Level Political Forum on Sustainable Development, available online: https://sustainabledevelopment.un.org/content/documents/16005Az erbaijan.pdf.

[8] Safer and Healthier Work for All - Modernisation of the EU Occupational Safety and Health Legislation and Policy, Communication from the Commission to the European Parliament, the Council, the Eropean Economic and Social Committee and the Committee of the Regions (on 10.1.2017), https://eurlex.europa.eu/legal-

con-

tent/EN/TXT/?qid=1524846123494\&uri=CELEX:52017DC0012.

[9] European Statistics on Accidents at Work (ESAW), 2011.

[10] Based on Eurostat, EU LFS ad hoc modules on accidents at work and work-related health problems 2007 and 2013.

[11] Indeed, $7.9 \%$ of persons who work or have worked before declare suffering from one or more work-related health problems caused or made worse by work, EU-27. Eurostat, 2013 EU-LFS ad hoc module on accidents at work and work-related health problems (online data code hsw_pb1), Commission staff working document ex-post evaluation of the European Union occupatinal safety and health Directives (REFIT evaluation) Accompanying the document communication from the Commission to the European Parliament, the Council, the European Economic and Social Committee and the Committee of the Regions Safer and Healthier Work for All Modernisation of the EU Occupational Safety and Health Legislation and Policy (on 10.1.2017), https://eurlex.europa.eu/legal-

content/EN/TXT/?qid=1524846123494\&uri=CELEX:52017SC001 0 .

[12] Work-related accidents and injuries cost EU €476 billion a year according to new global estimates, https://osha.europa.eu/en/highlights/eu-osha-presents-new-figurescosts-poor-workplace-safety-and-health-world-osh-congress

[13] Socio-economic costs of accidents at work and work-related ill health Key messages and case studies. European Commission, November, 2011. P.20.

[14] Calculating the international return on prevention for companies: costs and benefits of investments in occupational safety and health, International Social Security Association; 2013.

[15] By the Constituent Acts of the European Union, the European Social Charter has been attributed to us by the requirement of Article 151 of the Treaty on the Functioning of the European Union, according to which the European Union and the Member States have concluded the said agreement, having in mind the fundamental social rights such as those set out in the European Social Charter signed at Turin on 18 October 1961 and in the 1989 Community Charter of the Fundamental Social Rights of Workers, available online: http://eur-lex.europa.eu/resource.html?uri=cellar:41f89a281fc6-4c92-b1c8-03327d1b1ecc.0007.02/DOC_1\&format=PDF.

[16] Charter of Fundamental Rights of the European Union, available online: http://www.europarl.europa.eu/charter/pdf/text_en.pdf.

[17] Interinstitutional Proclamation on the European Pillar of Social Rights, https://eur-lex.europa.eu/legalcontent/EN/TXT/?uri=CELEX\%3A32017C1213\%2801\%29.

[18] Council Directive 89/391/EEC of 12 June 1989 on the introduction of measures to encourage improvements in the safety and health of workers at work, https://eur-lex.europa.eu/legalcontent/EN/TXT/?uri=CELEX:01989L0391-20081211

[19] Council Directive 92/57/EEC of 24 June 1992 on the implementation of minimum safety and health requirements at temporary or mobile construction sites (eighth individual Directive within the meaning of Article 16 (1) of Directive 89/391/EEC), https://eurlex.europa.eu/legal-content/EN/TXT/?uri=CELEX:01992L005720070627

[20] Commission staff working document «Ex-post evaluation of the European Union occupatinal safety and health Directives» (REFIT evaluation). Accompanying the document. Communication from the Commission to the European Parliament, the Council, the European Economic and Social Committee and the Committee of the Regions. Safer and Healthier Work for All - Modernisation of the EU Occupational Safety and Health Legislation and Policy (on 
10.1.2017), $\quad$ https://eur-lex.europa.eu/legal-

con-

tent/EN/TXT/?qid=1524846123494\&uri=CELEX:52017SC0010.

[21] Eurostat, ESAW (online data codes hsw_02_01 and hsw_02_02).

[22] EU SMES and sub-contracting, EIM Business \& Policy Research, 2009, P.24.

[23] DG EMPL, Employment and Social Developments in Europe 2015, Chapter 1.1. Self-employment and entrepreneurship.

[24] In particular, in the Association Agreement between the European Union and the European Atomic Energy Community and their Member States, of the one part, and Georgia, of the other part (Association Agreement between the European Union and the European Atomic Energy Community and their Member States, of the one part, and Georgia, of the other part) (available online: https://eurlex.europa.eu/legal-

content/EN/TXT/?qid=1524846123494\&uri=CELEX:02014A0830 (02)-20161110); in the Association Agreement between the European Union and the European Atomic Energy Community and their Member States, of the one part, and the Republic of Moldova, of the other part (Association Agreement between the European Union and the European Atomic Energy Community and their Member States, of the one part, and the Republic of Moldova, of the other part) (available online: https://eur-lex.europa.eu/legalcon-

tent/EN/TXT/?qid=1524846123494\&uri=CELEX:02014A0830(01) -20161019).

[25] Association Agreement between the European Union and its Member States, of the one part, and Ukraine, of the other part, https://eur-lex.europa.eu/legal-

content/EN/TXT/?qid=1524846123494\&uri=CELEX:22014A0529 (01)

[26] On Approval of Minimum Requirements for Occupational Safety at Temporary or Mobile Construction Plots: Order of the Ministry of Social Policy of Ukraine dated 23 June 2017 No. 1050, registered with the Ministry of Justice of Ukraine on September 08, 2017 under No. 1111/30979, available online: http://zakon5.rada.gov.ua/laws/show/z111117/print 1510136552882969

[27] For example, Italy referred to the decision of the First Chamber of the Court of 25 July 2008 on the case of the Commission of the European Communities against the Italian Republic (Case 504/06) (available online: http://curia.europa.eu/juris/document/document.jsf?text=\&docid=6 8150\&pageIndex $=0 \&$ doclang $=I T \&$ mode $=1$ st $\&$ dir $=\& o c c=$ first $\&$ part $=1 \& \mathrm{cid}=1195133)$, or the decision of the Fifth Chamber of the Court of 7 October 2010 (Case C-224/09) (available online: http://curia.europa.eu/juris/document/document.jsf?text=\&docid=7 9375\&pageIndex $=0 \&$ doclang $=$ en $\&$ mode $=1$ st $\&$ dir $=\& o c c=$ first $\&$ part $=1 \&$ cid=1194778)

[28] This is explicitly mentioned in Article 2 (a) of the Directive.

[29] Case C-518/15. Judgment of the Court. 21 February 2018, available online:

http://curia.europa.eu/juris/document/document.jsf?docid=199508 \&mode $=$ req $\&$ pageIndex $=1 \&$ dir $=\&$ occ $=$ first $\&$ part $=1 \&$ text $=\% 2522 \mathrm{c}$ oncept $\% 2$ Bof $\% 2 B \% 25 \mathrm{E} 2 \% 2580 \% 2598$ worker\%25E $2 \% 2580 \% 259$ $9 \% 2522 \&$ doclang $=\mathrm{EN} \& \mathrm{cid}=66611 \mathrm{\# ctx} 1$.

[30] Case C-216/15. Judgment of the Court. 17 November 2016, available on line: http://curia.europa.eu/juris/document/document.jsf?docid=185444 \&mode $=$ req \&pageIndex $=1 \&$ dir $=\&$ occ $=$ first \&part $=1 \&$ text $=\% 2522 \mathrm{c}$ oncept $\% 2 \mathrm{Bof} \% 2 \mathrm{~B} \% 25 \mathrm{E} 2 \% 2580 \% 2598$ worker\%25E2\%2580\%259 $9 \% 2522 \&$ doclang $=E N \&$ cid $=66611 \#$ ctx 1 .

[31] Case C-256/01. Judgment of the Court. 13 January 2004, available online:

http://curia.europa.eu/juris/document/document.jsf?text=\&docid=4 $8839 \&$ pageIndex $=0 \&$ doclang $=$ en $\&$ mode $=1$ st $\&$ dir $=\& o c c=$ first $\&$ part $=1 \&$ cid $=296684$.

[32] Council Directive 89/391/EEC of 12 June 1989 on the introduction of measures to encourage improvements in the safety and health of workers at work, available online: https://eur-lex.europa.eu/legalcontent/EN/TXT/?uri=CELEX:01989L0391-20081211. 